\title{
PEMAHAMAN KOSAKATA BAHASA INDONESIA \\ DALAM TEKS DESKRIPSI PADA PESERTA DIDIK KELAS IX-D \\ MTSN 2 BANJARMASIN
}

\author{
INDONESIA LANGUAGE UNDERSTANDING \\ IN THE TEXT DESCRIPTION OF STUDENTS IN IX-D CLASS \\ MTSN 2 BANJARMASIN
}

\author{
Muhammad Aulia Rahman; Rustam Effendi; Dewi Alfianti \\ Program Studi Pendidikan Bahasa dan Sastra Indonesia \\ FKIP Universitas Lambung Mangkurat \\ mhmauliarhm@gmail.com
}

\begin{abstract}
Abstrak
Penelitian ini bertujuan untuk mengukur pemahaman peserta didik terhadap kosakata bahasa Indonesia pada teks deskripsi. Penelitian ini menggunakan pendekatan kuantitatif dan metode deskriptif. Data dalam penelitian ini adalah hasil jawaban peserta didik pada soal yang diberikan, soal terdiri dari pilihan ganda, mengisi teks rumpang dan asosiasi kata. Sumber data penelitian ini adalah peserta didik kelas IX-D MTs Negeri 2 Banjarmasin. Teknik pengumpulan data dilakukan melalui tes berupa tes pilihan ganda, mengisi teks rumpang, dan membuat asosiasi kata. Teknik analisis data menggunakan teknik perhitungan SPSS (Statistical Package for the Social Sciences). Hasil penelitian ini menunjukkan bahwa pemahaman kosakata bahasa Indonesia dalam teks deskripsi pada peserta didik kelas IX-D berada pada kategori baik dengan rata-rata nilai 70 .
\end{abstract}

Kata Kunci: Pemahaman, Kosakata, Teks deskripsi

\begin{abstract}
This research is to measure students' understanding of Indonesian vocabulary in the description text. This study uses quantitative and descriptive methods. The data of this study are the results of the answers of the students on the questions given, the questions consist of multiple choices, content of rumpang text and word associations. The source of this research data is students of class IX-D MTs Negeri 2 Banjarmasin. The technique of collecting data is done through tests that consist of multiple choice tests, filling up of text, and making word associations. Data analysis techniques using SPSS (Statistical Package for the Social Sciences) calculation techniques. The results of this study show how to understand Indonesian vocabulary in the description text of IX-D class students in a good category with an average value of 70 .
\end{abstract}

Keywords: Understanding, Vocabulary, Description text 


\section{Pendahuluan}

Pemahaman kosakata merupakan hal yang penting karena dapat menjadi sarana pendukung untuk mempelajari disiplin ilmu khususnya mata pelajaran di sekolah. Yulia dkk (2013:1) berpendapat bahwa penguasaan kosakata adalah kegiatan menguasai atau kemampuan memahami dan menggunakan kata-kata yang terdapat dalam suatu bahasa, baik bahasa lisan, maupun tulisan. Penguasaan kosakata sangat diperlukan karena semakin banyak kosakata yang dimiliki seseorang, semakin mudah pula ia menyampaikan dan menerima informasi, bahkan kosakata dapat dipakai sebagai ukuran kepandaian seseorang.

Pembelajaran kosakata di sekolah hampir diserap di semua mata pelajaran. Dalam pembelajaran kosakata, peserta didik dituntut untuk tidak hanya mengetahui dan memahami kosakata sehari-hari tetapi juga kosakata bidang ilmu. Setiap bidang ilmu memiliki kosakata yang khas dan harus dipahami oleh peserta didik. Dengan pemahaman terhadap kosakata yang khas bidang ilmu tersebut akan membantu peserta didik dalam proses pembelajaran.

Sebagaimana ciri pembelajaran bahasa Indonesia pada Kurikulum 2013 yaitu pembelajaran bahasa Indonesia berbasis teks. Kurikulum 2013 ini sangat berbeda dengan kurikulum terdahulu yaitu kurikulum KTSP di mana pembelajaran bahasa Indonesia berbasis empat keterampilan berbahasa. Dari banyaknya teks yang ada dalam pembelajaran bahasa Indonesia sesuai dengan Kurikulum 2013, satu di antaranya adalah teks deskripsi.

Kosasih (2006:26) berpendapat bahwa teks deskripsi adalah karangan yang menggambarkan suatu objek dengan tujuan agar pembaca merasa seolah-olah melihat sendiri objek yang digambarkan itu. Dari definisi tersebut, dapat ditelusuri bahwa dalam teks deskripsi terdapat penggambaran terhadap suatu objek, menggunakan kosakata khusus sehingga memerlukan pemahaman terhadap setiap kosakatanya. Sebagaimana teks lainnya, teks deskripsi mengandung banyak kosakata yang harus dipahami oleh peserta didik untuk menangkap tujuan dalam bacaan. Oleh karena itu, pemahaman terhadap kosakata ikut berperan penting sebagai pendukung keberhasilan peserta didik dalam mempelajari teks deskripsi.

Saat peserta didik memiliki pemahaman dan penguasaan pada kosakata yang baik, akan mendukung peserta didik dalam memahami teks deskripsi. Pemahaman terhadap kosakata melalui kegiatan terbimbing di kelas oleh pengajar pada pembelajaran Bahasa Indonesia, khususnya teks deskripsi akan membawa peserta didik kepada pemaknaan dalam belajar sehingga pencapaian tujuan 
pembelajaran bahasa Indonesia dapat dikatakan berhasil.

Kesadaran terhadap pentingnya peran kosakata dalam mencapai hasil belajar harus dihidupkan. Kesadaran itu akan berimplikasi kepada kegiatan belajar mengajar yang menjadikan kosakata sebagai bagian penting pembelajaran yang harus diperhatikan dan ditingkatkan. Selain itu, pengkajian lebih dalam terkait pemahaman kosakata untuk menunjang ketercapaian dalam pembelajaran pada kegiatan belajar mengajar di kelas, perlu dilakukan. Pengkajian ini dapat dilakukan dengan berbagai sarana. Dalam hal ini, sarana yang tepat untuk mengukur pemahaman terhadap pemahaman kosakata adalah teks deskripsi. Sebagaimana penjelasan sebelumnya, teks deskripsi memuat kosakata khusus untuk memahami objek yang digambarkan. Oleh sebab itu, semakin banyak kosakata khusus yang terdapat dalam bacaan, semakin banyak pula hal yang harus dipahami untuk menerima informasi dalam bacaan.

Penelitian serupa pernah dilakukan oleh Pramesti pada tahun 2015 dengan judul "Peningkatan Penguasaan Kosakata Bahasa Indonesia dalam Keterampilan Membaca melalui Teka-Teki Silang”. Persamaan penelitian ini dengan penelitian yang akan dilakukan terletak pada variabel yaitu kosakata bahasa Indonesia.
Sedangkan perbedaannya terletak pada pengaplikasian kosakata

Berdasarkan uraian di atas, peneliti tertarik untuk meneliti lebih lanjut mengenai pemahaman kosakata pada bidang studi Bahasa Indonesia dalam teks deskripsi untuk mengetahui tingkat pemahaman kosakata peserta didik.

\section{Metode Penelitian}

Penelitian ini menggunakanpendekatan kuantitatif dan metode deskriptif. Data dalam penelitian ini adalah hasil jawaban peserta didik pada soal yang diberikan, soal terdiri dari pilihan ganda, mengisi teks rumpang dan asosiasi kata. Sumber data penelitian ini adalah peserta didik kelas IX-D MTs Negeri 2 Banjarmasin. Teknik pengumpulan data dila-kukan melalui tes berupa tes pilihan ganda, mengisi teks rumpang, dan membuat asosiasi kata. Teknik analisis data menggunakan teknik perhitungan SPSS (Statistical Package for the Social Sciences).

\section{Hasil Penelitian dan Pembahasan}

Penelitian ini memperoleh data dari tes penguasaan kosakata bahasa Indonesia. Tes penguassan kosakata bahasa Indoneisa terdiri dari pilihan ganda, mengisi teks rumpang, dan asosiasi kata. Tes tersebut dilaksanakan dalam tataran waktu $2 \times 40$ menit, peserta didik menjawab sesuai pengetahuan dan pemahamannya pada kosakata Bahasa Indonesia. 


\section{Pemahaman Kosakata Menjawab Pilihan Ganda}

Berdasarkan tes yang telah dilaksana-kan, hasil yang didapat dari 40 orang. Tes pilihan ganda digunakan sebagai alat untuk mengetahui pemahaman peserta didik dalam kosakata. Soal pilihan ganda sebanyak 20 soal, mempunyai skor 5 dalam 1 soal sehingga skor maksimal adalah 100. Skor tertinggi dalam tes pemahaman kosakata, yaitu 90 dan skor terendah dalam tes pemahaman kosakata, yaitu 30 .

Berdasarkan tes yang telah dilaksana-kan, hasil yang didapat dari 40 orang, menunjukkan bahwa penguasaan kosakata yang disajikan melalui pilihan ganda memiliki variasi jawaban. Variasi tersebut menjadi ukuran kemampuan penguasaan kosakata bahasa Indonesia peserta didik di kelas IX-D MTsN 2 Banjarmasin. Berikut uraian jawaban pilihan ganda yang telah disebutkan.

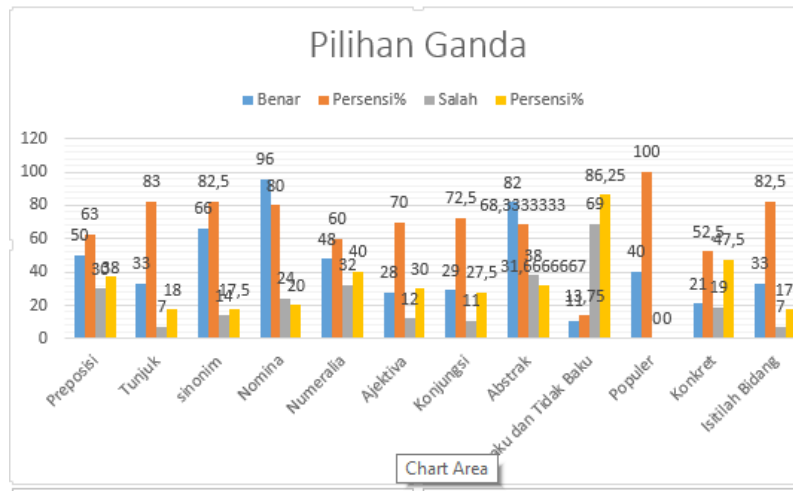

Gambar 1.Hasil jawaban terhadap soal kosakata pilihan ganda

\begin{tabular}{|c|c|c|c|c|c|}
\hline \multicolumn{6}{|c|}{ Deskripsi statistik pilihan ganda } \\
\hline & $\mathrm{N}$ & Rerata & $\begin{array}{l}\text { Standar } \\
\text { Deviasi }\end{array}$ & Minimum & Maksimum \\
\hline Pilihan ganda & 40 & 67,1250 & 15,56160 & 30,00 & 90.00 \\
\hline Valid N & 40 & & & & \\
\hline
\end{tabular}

Gambar 2.Hasil jawaban peserta didik menjawab soal pilihan ganda.

Berdasarkan tabel di atas dapat diketahui bahwa rata-rata nilai peserta didik adalah 67,1250, standar deviasi nilainya 15,56160 . Standar deviasi digunakan untuk mengetahui nilai statistik untuk menentu-kan sebaran data dalam sampel, minimum dan maksimum. Nilai minimum (Xmin) sebesar 30,00 untuk menentukan nilai data statistik terkecil, dan nilai maksimum (Xmax) sebanyak 90,00 untuk menentukan nilai data statistik tertinggi.

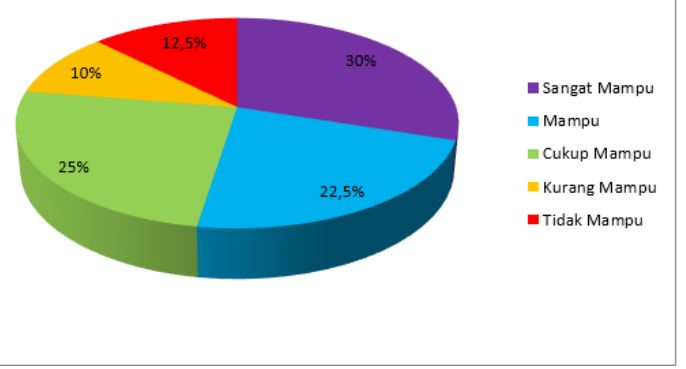

Gambar 3.Hasil pengkateogorian dari nilai peserta didik dalam menjawab soal pilihan ganda

Berdasarkan grafik di atas dapat diketahui bahwa $52,5 \%$ peserta didik dalam menjawaba soal pilihan ganda berada pada kategori mampu dan sangat 
mampu, 25\% cukup mampu, dan 22,5\% berada pada ketogri kurang mampu dan tidak mampu. Rata-rata nilai peserta didik dalam menjawab pilihan ganda sebesar 67,0 yang menujukkan bahwa kemampuan menjawab soal pilihan ganda peserta didik kelas 9D MTs Negeri 2 Banjaramsin berada pada kategori Cukup mampu.

\section{Pemahaman Kosakata Melalui Mengisi}

\section{Teks Rumpang}

Berdasarkan tes yang telah dilaksanakan, hasil yang didapat dari 40 orang. Tes mengisi teks rumpang digunakan sebagai alat untuk mengetahui pemahaman peserta didik dalam kosakata. Teks rumpang terdiri 15 soal. Untuk memperoleh skor dalam teks rumpang, nilai yang di peroleh dibagi nilai maksimal dikali 100 sehingga skor maksimal adalah 100. Skor tertinggi dalam tes pemahaman kosakata, yaitu 87 dan skor terendah dalam tes pemahaman kosakata, yaitu 27.

Berdasarkan tes yang telah dilaksanakan, hasil yang didapat dari 40 orang, menunjukkan bahwa penguasaan kosakata yang disajikan melalui pilihan teks rumpang memiliki variasi jawaban. Variasi tersebut menjadi ukuran kemampuan penguasaan kosakata bahasa Indonesia peserta didik di kelas IX-D MTsN 2 Banjarmasin. Berikut uraian jawaban pilihan ganda yang telah disebutkan.

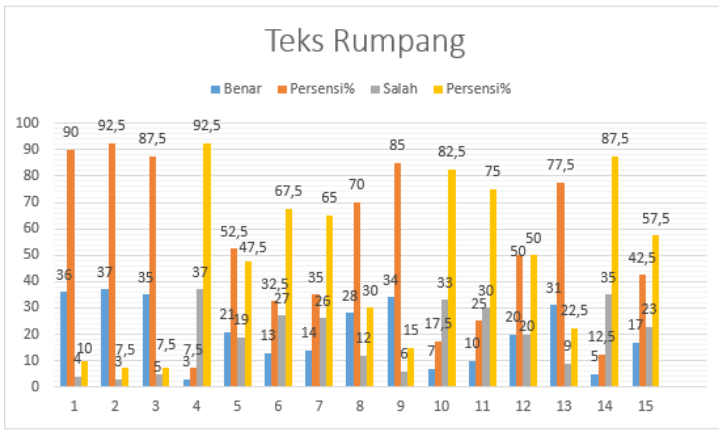

Gambar 4.Hasil pengkateogorian dari nilai peserta didik dalam mengisi teks rumpang Berdasarkan grafik di atas, setiap soal memiliki keragaman jumlah jawaban benar dan salah. Berikut uraian terkait jumlah jawaban benar dan salah pada setiap soal.

1. Soal nomor 1, terdapat sebanyak 36 dari 40 peserta didik berhasil melengkapi soal rumpang yang disediakan dengan persentase $90 \%$ sehingga dapat dikategorikan sangat mampu.

2. Soal nomor 2, terdapat sebanyak 37 dari 40 peserta didik berhasil melengkapi soal rumpang yang disediakan dengan persentase 92,5\% sehingga dapat dikategorikan sangat mampu.

3. Soal nomor 3 , terdapat sebanyak 35 dari 40 peserta didik berhasil melengkapi soal rumpang yang disediakan dengan persentase $87,5 \%$ sehingga dapat dikategorikan sangat mampu. 
4. Soal nomor 4, terdapat sebanyak 3 dari 40 peserta didik berhasil melengkapi soal rumpang yang disediakan dengan persentase 7,5\% sehingga dapat dikategorikan tidak mampu.

5. Soal nomor 5, terdapat sebanyak 21 dari 40 peserta didik berhasil melengkapi soal rumpang yang disediakan dengan persentase $52,5 \%$ sehingga dapat dikategorikan kurang mampu.

6. Soal nomor 6, terdapat sebanyak 13 dari 40 peserta didik berhasil melengkapi soal rumpang yang disediakan dengan persentase $32,5 \%$ sehingga dapat dikategorikan kurang mampu.

7. Soal nomor 7 , terdapat sebanyak 14 dari 40 peserta didik berhasil melengkapi soal rumpang yang disediakan dengan persentase $35 \%$ sehingga dapat dikategorikan kurang mampu.

8. Soal nomor 8, terdapat sebanyak 28 dari 40 peserta didik berhasil melengkapi soal rumpang yang disediakan dengan persentase $70 \%$ sehingga dapat dikategorikan mampu.
9. Soal nomor 9, terdapat sebanyak 34 dari 40 peserta didik berhasil melengkapi soal rumpang yang disediakan dengan persentase $85 \%$ sehingga dapat dikategorikan sangat mampu.

10. Soal nomor 10 , terdapat sebanyak 7 dari 40 peserta didik berhasil melengkapi soal rumpang yang disediakan dengan persentase $17,5 \%$ sehingga dapat dikategorikan sangat mampu.

11. Soal nomor 11, terdapat sebanyak 10 dari 40 peserta didik berhasil melengkapi soal rumpang yang disediakan dengan persentasi $25 \%$ sehingga dapat dikategorikan tidak mampu.

12. Soal nomor 12 , terdapat sebanyak 20 dari 40 peserta didik berhasil melengkapi soal rumpang yang disediakan dengan persentase $50 \%$ sehingga dapat dikategorikan kurang mampu.

13. Soal nomor 13 , terdapat sebanyak 31 dari 40 peserta didik berhasil melengkapi soal rumpang yang disediakan dengan persentase $77,5 \%$ sehingga dapat dikategorikan mampu. 
14. Soal nomor 14, terdapat sebanyak 5 dari 40 peserta didik berhasil melengkapi soal rumpang yang disediakan dengan persentase $12,5 \%$ sehingga dapat dikategorikan tidak mampu.

15. Soal nomor 15 , terdapat sebanyak 17 dari 40 peserta didik berhasil melengkapi soal rumpang yang disediakan dengan persentase $42,5 \%$ sehingga dapat dikategorikan sangat mampu.

\begin{tabular}{|l|l|l|l|l|l|}
\hline \multicolumn{6}{|l|}{ Deskripsi statistik teks rumpang } \\
\hline & N & Rerata & $\begin{array}{l}\text { Standar } \\
\text { Deviasi }\end{array}$ & Minimum & Maksimum \\
\hline $\begin{array}{l}\text { Pemahaman } \\
\text { (XI - D) }\end{array}$ & 40 & 52,9500 & 3,01767 & 27,00 & 87,00 \\
\hline Valid N & 40 & & & & \\
\hline
\end{tabular}

Gambar 5.Hasil jawaban peserta didik mengisi teks rumpang.

Berdasarkan tabel di atas dapat diketahui bahwa rata-rata nilai peserta didik adalah 52,9500, standar deviasi nilainya 3,01767. Standar deviasi digunakan untuk mengetahui nilai statistik untuk menentu-kan sebaran data dalam sampel, minimum dan maksimum. Nilai minimum (Xmin) sebesar 27,00 untuk menentukan nilai data statistik terkecil, dan nilai maksimum (Xmax) sebanyak 87,00 untuk menentukan nilai data statistik tertinggi.

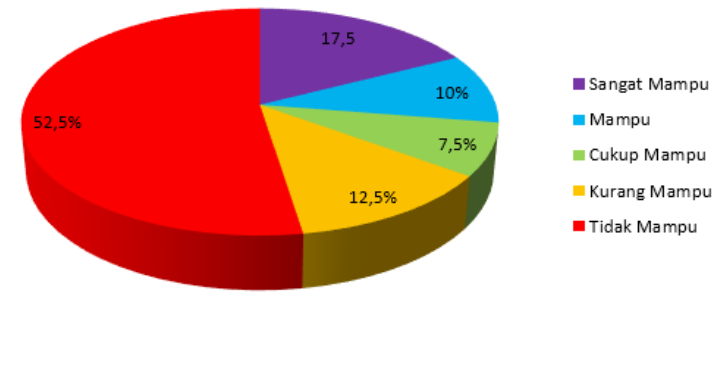

Gambar 6.Hasil pengkateogorian dari nilai peserta didik dalam mengisi teks rumpang

Berdasarkan grafik di atas dapat diketahui bahwa $27,5 \%$ peserta didik dalam menjawaba soal pilihan ganda berada pada kategori mampu dan sangat mampu, 7,5\% cukup mampu, dan 65\% berada pada ketogri kurang mampu dan tidak mampu. Rata-rata nilai peserta didik dalam menjawab pilihan ganda sebesar 53,0 yang menujuk-kan bahwa kemampuan mengisi teks rumpang peserta didik kelas 9D MTs Negeri 2 Banjaramsin berada pada kategori Kurang mampu.

\section{Pemahaman Kosakata Melalui Asosiasi}

Berdasarkan tes yang telah dilaksanakan dari mengasosiasikan kata, peneliti berharap menemukan variasi kata terhadap kata yang diasosiasikan. Hasil yang didapat dari 40 orang, menujukkan variasi kata yang ditemukan sebanyak 800 kata dari 10 kata yang diasosiasikan.

Berdasarkan tes yang telah dilaksanakan, hasil yang didapat dari 40 orang, menunjukkan bahwa penguasaan kosakata yang disajikan melalui pilihan 
teks rumpang memiliki variasi jawaban.

Variasi tersebut menjadi ukuran kemampu-an penguasaan kosakata bahasa Indonesia peserta didik di kelas IX-D MTsN 2 Banjarmasin. Berikut uraian jawaban pilihan ganda yang telah disebutkan.

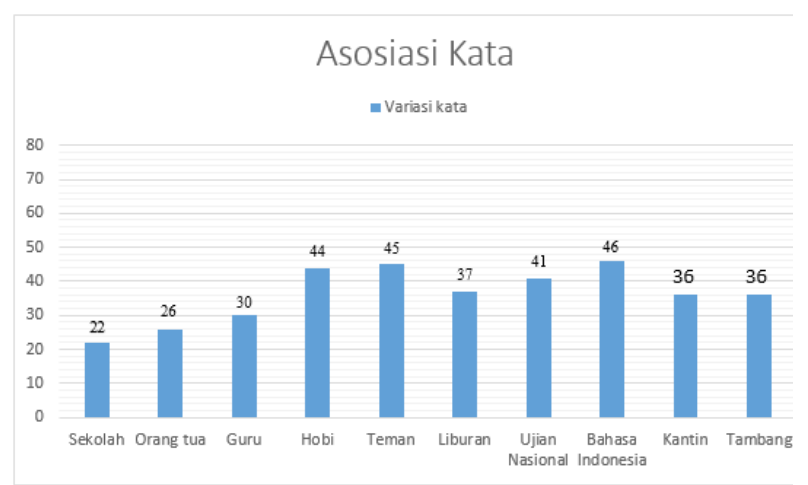

Gambar 7.Variasi asosiasi kata peserta didik.

Bersarkan grafiks batang di atas, dapat disimpulkan bahwa variasi kata terhadap asosiasi kata memilki jumlah yang berbeda. Variassi untuk asosiasi "sekolah" sebanyak 22 kata, "orang tua" sebanyak 26 kata, "Guru" sebanyak 30 kata, "hobi" sebanyak 44 kata, "teman" sebanyak 45 kata, "liburan" sebanyak 37 kata, "ujian nasional" sebanyak 41 kata, "bahasa Indonesia" sebanyak 46 kata, "kantin" sebanyak 36 kata, dan "tambang" sebanyak 36 kata.

\section{Pemahaman Kosakata dalam Teks Deskripsi}

Berdasarkan tes yang telah dilaksanakan terhadap dari 40 orang, dengan mengukur pemahaman kosakata bahasa Indonesia melalui tes pilihan ganda, mengisi teks rumpang dan asosiasi kata pada 45 soal menunjukan suatu simpulan. Untuk memperoleh skor dalam teks rumpang, nilai yang di peroleh dibagi nilia maksimal dikali 100 sehingga skor maksimal adalah 100. Dari hasil pengumpulan data yang telah dilakukan diperoleh hasil untuk pemahaman kosaka tertinggi mendapat skor 91,1 dan skor terendah 48,9 .

Berdasarkan uranin di atas, didapat-kan suatu simpulan terkait pemahaman kosakata bahasa Indonesia dalam teks deskripsi pada peserta didik kelas IX-D MTs Negeri 2 Banjarmasin. Simpulan tersebut dijabarkan atas nilai dan kategori dalam bentuk tabel dan grafik.

\begin{tabular}{|l|c|l|l|l|l|}
\hline \multicolumn{2}{|l|}{ Deskripsi Statistik Pemahaman } \\
\hline & N & Rerata & $\begin{array}{l}\text { Standar } \\
\text { Deviasi }\end{array}$ & Minimum & Maksimum \\
\hline $\begin{array}{l}\text { Pemahaman } \\
\text { (XI - D) }\end{array}$ & 40 & 69.2000 & 12.32924 & 46.00 & 91.00 \\
\hline Valid N & 40 & & & & \\
\hline
\end{tabular}

Gambar 8.Hasil pemahaman kosakata peserta didik.

Berdasarkan tabel di atas dapat diketahui bahwa rata-rata nilai peserta didik adalah 69.2000, standar deviasi nilainya 12.32924. Standar deviasi digunakan untuk mengetahui nilai statistik untuk menentu-kan sebaran data dalam sampel, minimum dan maksimum. Nilai 
minimum (Xmin) sebesar 46,00 untuk menentukan nilai data statistik terkecil, dan nilai maksimum (Xmax) sebanyak 91,00 untuk menentukan nilai data statistik tertinggi.

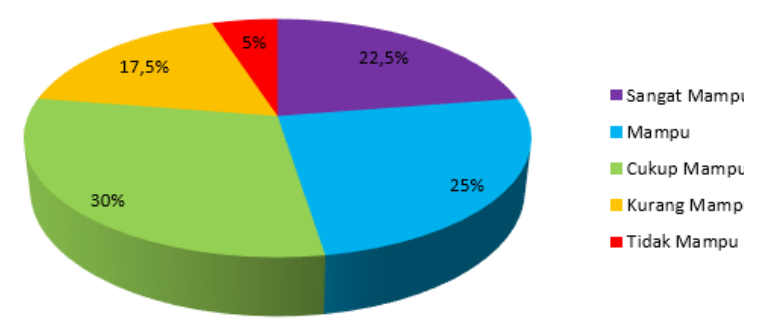

Gambar 9.Hasil pengkateogorian pemahaman kosakata peserta didik

Pada bagan di atas dapat diketahui bahwa $47,5 \%$ peserta didik dalam memahami kosakata bahasa Indonesia berada pada kategori mampu dan sangat mampu, 30\% cukup mampu, dan 22,5\% berada pada ketogri kurang mampu dan tidak mampu. Rata-rata nilai peserta didik dalam pemahaman kosakata bahas Indonesia sebesar 70 yang menujukkan bahwa kemampuan memahami kosakata peserta didik kelas 9D MTs Negeri 2 Banjaramsin berada pada kategori mampu.

\section{Simpulan}

Berdasarkan data hasil tes pemahaman kosakata bahasa Indonesia pada peserta didik kelas IX-D MTs Negeri 2 Banjarmasin dapat disimpulkan bahwa rata-rata pemahaman koskata peserta didik dalam menjawab soal pilihan ganda berada pada kategori cukup mampu dengan ratarata 67 , rata-rata pemahaman koskata peserta didik dalam mengisi teks rumpang berada pada kategori kurang mampu dengan rata-rata 53, Pemahaman kosakata peserta didik dengan mengasosiasikan kata memilki variasi jawaban, dari sepuluh kata yang diberikan ke peserta didik. Variasi untuk asosiasi "sekolah" sebanyak 22 kata, "orang tua" sebanyak 26 kata, "Guru" sebanyak 30 kata, "hobi" sebanyak 44 kata, "teman" sebanyak 45 kata, "liburan" sebanyak 3 kata, "ujian nasional" sebanyak 41 kata, "bahasa Indonesia" sebanyak 46 kata, "kantin" sebanyak 36 kata, dan "tambang” sebanyak 36 kata.

Pemahaman kosakata bahasa Indonesia dalam teks deskripsi pada peserta didik kelas IX-D MTs Negeri 2 Banjarmasin secara keseluruhan berada pada kategori cukup mampu dengan nilai rata-rata 67 , di mana nilai tertinggi memperoleh skor 91 dan terendah 48. Dengan rincian 16 orang dengan persentase $40 \%$ berada pada kategori mampu dan sangat mampu, 11 orang dengan persentase $27,5 \%$ berada pada kategori cukup mampu, dan 13 orang dengan persentase $32,5 \%$ berada pada kategori kurang mapu dan tidak mampu.

\section{Saran}

Penelitian mengenai kosakata bahasa Indonesia kedepanya harus lebih 
baik lagi. Penelitain mengenai kosakata bahasa Indonesia harus lebih diperbanyak lagi. Penelitian kosakata bahasa Indonesia selanjutnya dapat dilaksanakan di tempat lain dan cakupan yang lebih luas dari peneliti. Di mana penelitian ini hanya berada di satu kelas dan di satu sekolah saja. Bagi guru agar lebih meperhatikan dan meningkatkan pembelajaran kosakata.

\section{Daftar Pustaka}

Arikunto, Suharsimi. (2006). Dasar-dasar Evaluasi Pendidikan. Jakarta: PT. Bumi Aksara.

Chaer, Abdul. (2007). Leksikologi dan Leksikografi Indonesia. Jakarta: Rineka Cipta.

Elviza, Yulia, dkk. (2013). Peningkatan penguasaan Kosakata Melalui Teknik Permainan Teka-Teki Silang di Kelas VII A SMPN 2 Sungai Penuh. Jurnal. Pendidikan Bahasa dan Sastra Indonesua Vol. 1 No. 2 Maret 2013, Seri F 399-476. (Daring) diakses 20 Desember 2018.

Emzir. (2008). Metodologi Penelitia Pendidikan Kuatitatif \& Kualitatif. Jakarta. PT Grafindo Persada.

Keraf, Gorys. (2006). Diksi dan Gaya Bahasa. Jakarta: Gramedia Pustaka Utama.

Keraf, Gorys. (1981). Eksposisi dan Deskripsi. Ende-Flores. Nusa Indah.
Kridalaksana, Harimurti. (2005). Kelas Kata dalam Bahasa Indonesia. Jakarta. Gramedia Pustaka Utama.

Kosasih. (2006). Ketata Bahasaan dan Kesusastraan. Bandung: CV. Yrama Widya.

Kuswana. W.S. (2012). Taksonomi Kognitif. Bandung. PT. Remaja Rosdakarya. Mahsun. 2014. Teks dalam Pembelajaran Bahasa Indonesia. Jakarta: PT Raja Grafindo Persada.

Marahim, Ismail. (1994). Menulis Secara populer. Jakarta. Dunia Pustaka Jaya.

Nilariyanti, Eka. (2007). Pembelajaran Matematika Model Kooperatif Team Assisted Individualization (TAI) pada Siswa Kelas VII MTs Negeri Mulawarman Banjarmasin Tahun Pelajaran 2006/2007. Banjarmasin. UNLAM

Nirmalasari, Marintan. (2011). Pengembangan Model Memorization Learning dalam Menignkatkan Pemahaman Peserta Didik pada Pelajaran Kimia SMA. Edisi Khusus No.2, Agustus 2011 ISSN 1412-565X. (Daring) 25 Desember 2018.

Nurgiyantoro, Burhan. (2001). Penilaian dalam Pengajaran Bahasa dan Sastra.Yogyakarta: BPFE-Yogyakarta

Pateda, Mansoer.(1995). Kosakata dan Pengajarannya. Ende-Flores. Nusa Indah. 
Pramesti, Dewi Utami. (2015).

Peningkatan Penguasaan Kosakata

Bahasa Indonesia dalam Keterampilan Membaca Melalui Teka-Teki Silang. Jurnal Puitika volume 11 No. 1, April 2015. (Daring) diakses 20 Desember 2018.

Sari, Herda Wulan. (2011). Meningkatkan Kemampuan Siswa dalam Pembelajaran Seni Tari Melalui Tari Tirik Kuala Metode Demonstrasi pada Siswa Kelas VII-D di MTSN Mulawarman Banjarmasin. Banjarmasin. STIKIP

Semi, Athar. (2003). Menulis Efektif. Padang. Angkasa Raya.

Sudjana, Nana. (2013). Dasar-Dasar Proses Belajar Mengajar. Bandung. Sinar Baru Algensindo.

Tarigan, H.G. (2011). Pengajaran Kosakata. Bandung. Angkasa. 